\title{
Kültür Gökkuşağı Alabalığı (Oncorhynchus mykiss, W.)'nda Bazı Kok Türlerinin Neden Olduğu Enfeksiyonların Tespiti Üzerine Bir Çalışma*
}

\author{
Jale KORUN ${ }^{1 凶}$, Gülşen TiMUR ${ }^{2}$, Remziye Eda YARDIMCI ${ }^{2}$, Beytullah Ahmet BALCI ${ }^{1}$
}

1. Akdeniz Üniversitesi, Su Ürünleri Fakültesi, Antalya, TÜRKiYE.

2. İstanbul Üniversitesi, Su Ürünleri Fakültesi, İstanbul, TÜRKiYE.

\begin{tabular}{ccc}
\hline $\begin{array}{c}\text { Geliş Tarihi/Received } \\
\text { 23.05.2017 }\end{array}$ & Kabul Tarihi/Accepted & Yayın Tarihi/Published \\
25.12 .2017 & \\
\hline Bu makaleye atıfta bulunmak için/To cite this article: & \\
Korun J, Timur G, Yardımcı RE, Balcı BA: Kültür Gökkuşağı Alabalığı (Oncorhynchus mykiss, W.)'nda Bazı Kok Türlerinin \\
Neden Olduğu Enfeksiyonların Tespiti Üzerine Bir Çalışma. Atatürk Üniversitesi Vet. Bil. Derg., 13 (2): 149-158, 2018. \\
DOI: 10.17094/ataunivbd.315542
\end{tabular}

Öz: Bu çalışmanın amacı; Lactococcus garvieae, Streptococcus agalactiae (sinonim S. difficilis) ve S. iniae'nin Türkiye'nin Akdeniz bölgesindeki farklı gökkuşağı alabalı̆̆ı işletmelerinde gözlenen hastalık çıkışlarından sorumlu etkenler olup olmadıklarını araştırmaktır. Saha çalışmaları 2012 yılının Nisan ayında başlanmış ve Eylül ayında tamamlanmıştır. İzole edilen 55 suşu tanımlamak için fenotipik testler, API 20 strep ve PZR tekniği kullanılmıştır. Hasta balık örneklerinde deri renginin koyulaşması, kornea opaklaşması, ekzoftalmus, inoküler kanama, solgun solungaçlar ve yüzgeçlerin tabanında kanamalar gözlenmiştir. Histopatolojik olarak böbrek glomerulus ve tübüllerinde nekroz, hiperplazi ve füzyondan dolayı solungaç yapısının değişmesi, böbrekte $M M^{\prime}$ 'lerinde ağır birikimlerin bulunması, karaciğer hücrelerinde nekrotik dejenerasyonlar, dalak hücrelerinde ve midenin mukoza epitelyumunda boşalmalar tespit edilmiştir. Çalışma sonuçlarına göre, hasta gökkuşağı alabalıklarından Lactococcus garvieae izole edilirken, Streptococcus agalactiae ve S. iniae izole edilmemiştir. Bu sonuç ile, L. garvieae'nin bölgede örnekleme çalışması yapılan alabalık işletmelerinde görülen hastalık çıkışlarından sorumlu başlıca etken olduğu anlaşılmıştır. Çalışmada izolatların en az iki antimikrobiyal ajana dirençli oldukları bulunmuştur. Bu durum işletme koşullarında kullanılan antimikrobiyal ajanlara karşı bakteride artan direnç ile açıklanabilir. Antibiyogram duyarılık testi sonuçları hastalığa karşı mevcut aşı geliştirme çalışmalarının arttıııması gerektiğini çünkü bakteride direnç gelişimi artmakla birlikte, bu direnç gelişiminin ortamda bulunan diğer bakteri türlerine de aktarılabileceğini düşündürmektedir.

Anahtar Kelimeler: Oncorhynchus mykiss, Lactococcus garvieae, Streptococcus agalactiae, Streptococcus iniae.

\section{A Study on Detecting Infections Caused by Some Coccal Species on the Cultured Rainbow Trout (Oncorhynchus mykiss, W.)}

\begin{abstract}
The aim of this study was to investigate whether Lactococcus garvieae, Streptococcus agalactiae (synonym $S$. difficilis) and Streptococcus iniae were causative agents of disease outbreaks observed in different rainbow trout fish farms in the Mediterranean region of Turkey. The field studies were started in April of 2012 and completed in September. Phenotypic tests, the API 20 strep and PCR technique were used to identify the isolated 55 strains. Darkening of the skin colour, clouding of cornea, exophthalmus, intraocular hemorrhagy, pale gills and haemorrhages at the base of fins were observed in the diseased fish samples. Histopathologically, necrosis on the kidney glomeruli and tubules, change of gill structure due to hyperplasia and fusion, presence of heavy depositions in the MMCs in the kidney, necrotic degenerations in the hepatocytes, depletions of splenecytes and mucosa epithelium of the stomach were determined. According to the results of the study, Lactococcus garvieae was isolated from sick fish while Streptococcus agalactiae and S. iniae were not isolated. With this result, it was understood that L. garvieae was the main responsible agent for disease outbreaks in the trout farms that were sampled in the region. In the study, it was found that the isolates were resistant to at least two antimicrobial agents. This state can be explained by the increased resistance of bacteria against antimicrobial agents used in the farm conditions. The results of antibiogram susceptibility testing suggest that current vaccine development studies against disease should be increased because the development of resistance of bacteria increases, preoccupying that this resistance development may also be transmitted to other bacterial species in the environment.
\end{abstract}

Keywords: Oncorhynchus mykiss, Lactococcus garvieae, Streptococcus agalactiae, Streptococcus iniae.

国 Jale KORUN

Akdeniz Üniversitesi, Su Ürünleri Fakültesi, Antalya, TÜRKiYE.

e-posta: jalekorun@akdeniz.edu.tr

*Bu çalışma, Jale KORUN'un Akdeniz Üniversitesi BAP tarafından 201101.0111.001 proje kodu ile desteklenen, 'Kültürü Yapılan Gökkuşağı Alabalıklarında (Oncorhynchus mykiss, W.) Bazı Streptokok Türlerinin Neden Olduğu Enfeksiyonların Tespiti Üzerine Bir Çalışma' başlıklı Araştırma Projesinin bir kısmından özetlenmiştir. 
GiRiş

B alıklarda gözlenen hastalık gelişimi; hassas konak, virulent mikroorganizma ve çevresel faktörlerin karşılıklı etkileşimini içeren karmaşık bir süreç (1) olup işletme koşullarında bulaşıcı hastalıklar su ürünleri üretimi üzerinde sınırlayıcı bir etkiye sahiptir. Bu hastalıklar arasında yer alan bakteriyel enfeksiyonlar, ülkemizde dahil olmak üzere dünyanın çeşitli bölgelerinde yetiştiriciliği yapılan kültür balıklarında görülmüştür (2-4). Streptokokkozis ve/veya Laktokokkozis tüm dünyada gökkuşağı alabalığı, tavşan balığı, Asya levreği, çipura ve doğal kefal dahil çeşitli balık türlerini etkileyen yaygın bir hastalık olup ilk streptokok enfeksiyonu 1958 yılında Japonya da kültür gökkuşağı alabalığında gözlenmiştir (5-7). Hastalığın etkenleri olarak çok sayıda bakteri türünün bildirilmesine karşın en yaygın olarak Streptococcus iniae, S. agalactiae (sinonim $S$. difficilis), S. dysgalactiae, $S$. parauberis ve Lactococcus garvieae türlerinin izole edildiği bildirilmiştir $(6,7)$. Streptokokkozis ve/veya Laktokokkozis hemorajik septisemi ile karakterize olup hastalıkta gözlenen klinik bulgular olarak iki taraflı ekzoftalmi, gözlerde kanama ve opaklaşma, deri renginde koyulaşma ile vücudun yan kısımlarında ve yüzgeç tabanlarında peteşiyal kanamaların varlığı rapor edilmiştir (7). Hasta balıklarda dalak, kalp, böbrek, beyin ve bağırsak başlıca etkilenen organlar olduğu bildirilmiştir (8). Ülkemizde L. garvieae'nin ilk izolasyonu Diler ve ark. (9) tarafından 2002 yılında gökkuşağı alabalığından bildirilmiştir. O tarihten günümüze kadar, etken Türkiye'nin farklı bölgelerinde kültürü yapılan gökkuşağı alabalığı, kalkan ve levrek balıklarından da rapor edilmiştir (10). Bu çalışma ile Muğla ve Antalya civarındaki farklı alabalık işletmelerindeki hastalık çıkışlarından Lactococcus garvieae, Streptococcus agalactiae (sin. S. difficilis) ve $S$. iniae türlerinin sorumlu olup olmadıklarının araştırılması amaçlanmıştır.

\section{MATERYAL ve METOT}

Çalışma Antalya iline kayıtlı iki, Muğla çevresinde dört olmak üzere toplam altı farklı alabalık işletmesinde gerçekleştirildi. Örnekleme çalışmalarına su sıcaklığının $18{ }^{\circ} \mathrm{C}$ olduğu Nisan ayında başlanılıp su sıcaklığının $25{ }^{\circ} \mathrm{C}$ olduğu Eylül ayında tamamlandı. Çalışma süresince vücut ağırlıkları 100 g'dan 295 g'a kadar değişen toplam 145 hasta balık kullanılmıştır.

\section{Parazitolojik ve Bakteriyolojik Inceleme}

Bakteriyolojik çalışma öncesi balıklar ekto ve/veya endoparazit yönünden incelenmiştir. Daha sonra, hasta balıkların karaciğer, dalak ve ön böbreğinden Brain Heart Infusion Agar (BHIA)'a ekimler yapılarak 48 saat süre ile $24 \pm 2^{\circ} \mathrm{C}$ de inkübe edilmiştir. Bu süre sonunda gelişme gösteren bakteri kolonilerinden altkültürler yapılmıştır. Suşların fenotipik özelliklerini belirlemek amacı ile Gram boyama, hareket, sitokrom oksidaz ve katalaz ile $\% 5$ koyun kanı içeren Nutrient Agar da (NA) hemoliz testleri de dahil olmak üzere bir dizi standart biyokimyasal testler uygulanmıştır $(4,11)$. Bakteri suşlarının hızlı tanımlanmasında API web referans tanı sistemi de uygulanmıştır. Çalışmada pozitif kontrol olarak Streptococcus agalactiae (ATCC 12401-20), S. pyogenes (ATCC 19615) ve Lactococcus garvieae (ATCC 43921), negatif kontrol olarak ise Aeromonas hydrophila (ATCC 1950) çalışmaya dahil edilmiştir. Çalışmanın yapılabilmesi için Akdeniz Üniversitesi Deney Hayvanları Yerel Etik Kurulu'nun onayı alınmıştır. Sayı: 2011.10.01.

\section{Antimikrobiyal Duyarlılığını Belirleme}

Hasta balıklardan izole edilen 55 suşun antimikrobiyal hassasiyet durumları Mueller-Hinton agar (MHA) da disk difüzyon yöntemi kullanılarak tespit edilmiştir (12). Çalışmada sırasıyla şu 
antimikrobiyaller kullanılmıştır: ampisilin (AMP, 10 $\mu \mathrm{g})$, basitrasin $(B C D, 0.04 \mu \mathrm{g})$, eritromisin $(E 15,15$ $\mu \mathrm{g})$, flumekuin (UB30, $30 \mu \mathrm{g}$ ), furazolidon (FR15, 15 $\mu \mathrm{g})$, kanamisin $(\mathrm{K} 30,30 \mu \mathrm{g})$, oksitetrasiklin (OT30, 30 $\mu \mathrm{g})$, streptomisin $(\mathrm{S} 10,10 \mu \mathrm{g})$ ve trimetoprim (W5, 5 $\mu \mathrm{g})$.

\section{DNA Ekstraksiyonu ve Moleküler Tanımlama}

Bakteriyel izolatların konfirmasyonu polimeraz zincir reaksiyonu (PZR) tekniği kullanılarak yapılmıştır. Bu amaçla, ticari olarak satın alınan Ready-To-Go TM PCR Beads kiti $(0.5 \mathrm{ml}$ tüpler içerisinde boncuk şeklinde liyofilize buffer, nükleotid ve Taq DNA polimeraz içeren 100 reaksiyonluk) kullanılmışır. Liyofilize boncuklar son konsantrasyonu $25 \mu \mathrm{l}$ olacak şekilde hesaplanarak $22 \mu \mathrm{l}$ distile suda çözdürülerek, üzerine ileri ve geri primer çiftinden $2 \mu \mathrm{l}$ ve $1 \mu \mathrm{l}$ DNA örneği eklenmiştir. L. garvieae'nin tanımlanması için türe özgü 1100 bç uzunluğunda bant oluşturan primer çifti PLG-1 (5'CATAACAATGAGAATCGC-3') ve PLG-2 (5'GCACCCTCGCGGGTTG-3') kullanılmıştır (13). Zlotkin ve ark. (13)'nın uyguladığı yöntemde minör değişiklikler yapmış olan Ravelo ve ark. (14)'nın uyguladığı döngüler kullanılarak, ilk denatürasyon 94 ${ }^{\circ} \mathrm{C}$ de $3 \mathrm{dk}$, diğerleri $94{ }^{\circ} \mathrm{C}$ de $1 \mathrm{dk}$, primer bağlanması $56{ }^{\circ} \mathrm{C}$ de $1 \mathrm{dk}$ ve uzama (polimerizasyon) $72{ }^{\circ} \mathrm{C}$ de $1.5 \mathrm{dk}$, son uzamada ise $72{ }^{\circ} \mathrm{C}$ de $10 \mathrm{dk}$ olacak şekilde toplam 35 döngü gerçekleştirilmiştir. PZR yöntemi ile Streptococcus agalactiae' in tanımlanması için Mata ve ark. (7)'nın tanımladığı 192 bç'lik Sdi61 (5'-AGGAAACCTGCCATTTGCG-3') ve Sdi252 (5'-CAATCTATTTCTTA-3') spesifik primer çiftleri ve uyguladığı döngüler, $S$. iniae'nin tanımlanması içinse Pourgholam ve ark. (15)'nın tanımladığı 554 bç'lik ileri ve geri primer çiftleri $F$ (5'-CTCTGTCCCGAAGCAAAATC- $\left.3^{\prime}\right)$ ve $\mathrm{R}$ (5'AACTAACCAGAAAGGGACGC-3') ile uyguladığı döngüler kullanılmıştır. Bu çalışmada S. agalactiaea (ATCC 29178), S. pyogenes (ATCC 19615) ve $L$. garvieae (ATCC 43921) referans bakteri türlerinden elde edilen $1 \mu$ l'lik DNA örnekleri pozitif kontrol, $A$. hydrophila (ATCC 19570) suşundan elde edilen 1

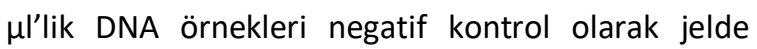

yürütülmüştür. Elde edilen PZR ürünleri özel bir laboratuara gönderilerek dizi (sekans) analizleri yaptırılarak her suş için Gen Bankası nüklotid blast işlemi ile en yakın ve benzerlik oranları tespit edilmiştir.

\section{Histopatolojik Analizler}

Nekropsi sonrasında hasta balıkların solungaçları ile iç organlarından örnekler alınarak $\% 10^{\prime}$ luk tamponlanmış formalin solüsyonunda fikse edilmiştir. Fiksasyon sonrası dokular çeşitli alkol serilerinden geçirilerek sıvı parafine gömülmüştür. 5 $\mu \mathrm{m}$ kalınlığında kesitler alınarak hematoksilen ve eosin ile boyanmıştır (16). Dokularda gözlenen patolojik değişiklikler tespit edilerek fotoğrafları çekilmiştir.

\section{BULGULAR}

$\mathrm{Bu}$ araştırmada hastalıktan etkilenen balıklarda iştah kaybı ile birlikte yem alımında azalma ve hareketlerinde durgunluk gözlenmiştir. Balıkların dış muayenesinde gözlerde bilateral ekzoftalmi, hemoraji ve opaklaşma, solungaçlarda solgunluk, deri renginde koyulaşma, karın kısmında şişkinlik, bazı balıklarda çenelerde hemoraji ve anal prolapsus da tespit edilmiştir. Nekropside, vücut kasında, hava kesesinde hemoraji, karaciğerde ekimoz, dalağın renginde koyulaşma, splenomegaly, böbrekte erime ile bağırsağın sarımsı kanlı sıvı içerdiği de gözlenmiştir. Enfekte balıkların bakteriyolojik muayenesinde hareketsiz, Gram-pozitif ve kısa zincir oluşturan kok şekilli bakterilerin varlığı tespit edilmiştir. Bakteriler fenotipik özelliklerine göre Lactococcus garvieae olarak identifiye edilmiştir. İzole edilen 55 L. garvieae suş fermentatif, sitokrom oksidaz ve katalaz negatif, Voges-Proskauer (VP) pozitif olup $45{ }^{\circ} \mathrm{C}$ de gelişme gösterirken \%5 koyun kanı ilaveli nutrient agarda $\alpha$-hemolitik koloniler oluşturmuştur. Suşların \%6.5 $\mathrm{NaCl}$ de üredikleri ve arabinoz, mannitol, sorbitol ve ksilozdan asit ürettikleri tespit edilmiştir. MacConkey agarda ise koloni oluşumu tespit edilmemiştir. Suşların diğer özellikleri Tablo 1 de verilmiştir. 
Tablo 1. Hasta gökkuşağı alabalıklarından izole edilen 55 L. garvieae suşu ile referans türlerin biyokimyasal özellikleri.

Table 1. Biochemical characteristics of the 55 L. garvieae strains and reference bacterial species.

\begin{tabular}{|c|c|c|c|c|c|c|}
\hline Özellik & İzolatlar & $\begin{array}{c}\text { L. garvieae } \\
\text { (ATCC 43921) }\end{array}$ & $\begin{array}{c}\text { S. agalactiae (ATCC } \\
12401-20)\end{array}$ & $\begin{array}{c}\text { S. pyogenes } \\
\text { (ATCC 19615) }\end{array}$ & S. iniae* & $\begin{array}{r}\text { A. hydrophila } \\
\text { (ATCC 1950) }\end{array}$ \\
\hline Gram & + & + & + & + & + & - \\
\hline Hareket & - & - & - & - & . & + \\
\hline Katalaz & - & - & - & - & - & + \\
\hline Oksidaz & - & - & - & - & . & + \\
\hline $\mathrm{O} / \mathrm{F}$ & $\mathrm{F}$ & $\mathrm{F}$ & $\mathrm{F}$ & $\mathrm{F}$ & . & $\mathrm{F}$ \\
\hline $\mathrm{H}_{2} \mathrm{~S}$ & - & - & - & - & - & + \\
\hline $\mathrm{ADH}$ & + & + & + & + & $\% 71+$ & - \\
\hline LDC & - & - & - & - & . & - \\
\hline ODC & - & - & - & - & . & - \\
\hline Hemoliz & $\alpha$ & $\alpha$ & $\beta$ & $\alpha$ & $\beta$ & $\beta$ \\
\hline VP & + & + & - & - & . & - \\
\hline MR & + & + & + & + & . & + \\
\hline \multicolumn{7}{|l|}{ Hidroliz: } \\
\hline Jelatin & - & - & + & - & . & + \\
\hline Nişasta & - & - & + & + & . & + \\
\hline $\begin{array}{c}\text { Nitrat } \\
\text { indirgeme }\end{array}$ & - & - & - & - & . & + \\
\hline ONPG & - & - & - & - & . & + \\
\hline Sitrat & - & - & - & - & . & + \\
\hline \multicolumn{7}{|l|}{ Gelişme: } \\
\hline $4^{\circ} \mathrm{C}$ & - & - & + & + & . & + \\
\hline $37^{\circ} \mathrm{C}$ & + & + & + & + & . & + \\
\hline $45^{\circ} \mathrm{C}$ & + & + & - & - &. & + \\
\hline \multicolumn{7}{|l|}{ Gelişme: } \\
\hline$\% 0 \mathrm{NaCl}$ & + & + & + & + & . & + \\
\hline$\% 2 \mathrm{NaCl}$ & + & + & + & + &. & + \\
\hline$\% 4 \mathrm{NaCl}$ & + & + & + & + & . & + \\
\hline$\% 6 \mathrm{NaCl}$ & + & + & + & + & . & + \\
\hline$\% 6.5 \mathrm{NaCl}$ & + & + & - & - & . & + \\
\hline$\% 8 \mathrm{NaCl}$ & - & - & - & - & . & - \\
\hline \multicolumn{7}{|l|}{$\begin{array}{l}\text { Şekerlerden } \\
\text { asit üretimi: }\end{array}$} \\
\hline Arabinoz & - & - & + & + & . & + \\
\hline Früktoz & + & + & + & + & + & + \\
\hline Galaktoz & + & + & + & + & + & + \\
\hline Glukoz & + & + & + & + & + & + \\
\hline İnositol & + & + & + & + & . & + \\
\hline Mannitol & + & + & - & - & + & - \\
\hline Mannoz & + & + & + & + & . & + \\
\hline Sorbitol & + & + & - & - & - & - \\
\hline Sakkaroz & + & - & + & + & + & + \\
\hline Ksiloz & + & + & - & - & - & - \\
\hline $\begin{array}{c}\text { MacConkey } \\
\text { Agar }\end{array}$ & - & - & - & - & . & + \\
\hline
\end{tabular}

API 20 strep sonuçlarına göre, 50 izolat \%92.4 olasılık ile Lactococcus lactis subsp. lactis olarak tanımlanırken (profil no: 1043011), 5 izolat \%89.3 olasılık ile Lactococcus spp. (profil no: 1003010) olarak tanımlanmıştır. Bu çalışmada suşların tür tespitinde PZR tekniğinden de yararlanılmıştır. PZR sonuçlarına göre, L. garvieae için hedef genin çoğaltılması ile PZR ürünleri 55 suş için 1100 bç'lik 
amplikon verdiği (Şekil 1) ancak Streptococcus agalactiae ve $S$. pyogenes türleri için amplikon ürünlerinin gözlenmediği tespit edilmiştir. Suşların sekans analizlerine ait ham dizi verileri Chromas-Pro 1.7,5 programı kullanılarak pasta formatına çevrilip temizlenerek, tek dizi haline getirilmiştir. Gen Bankası nükleotid blast işlemi ile en yakın türler ve benzerlik oranları her suş için tespit edilmiştir. Sonuçlar L. garvieae için yüksek benzerlik gösterdiği (\%98-100) anlaşılmıştır.

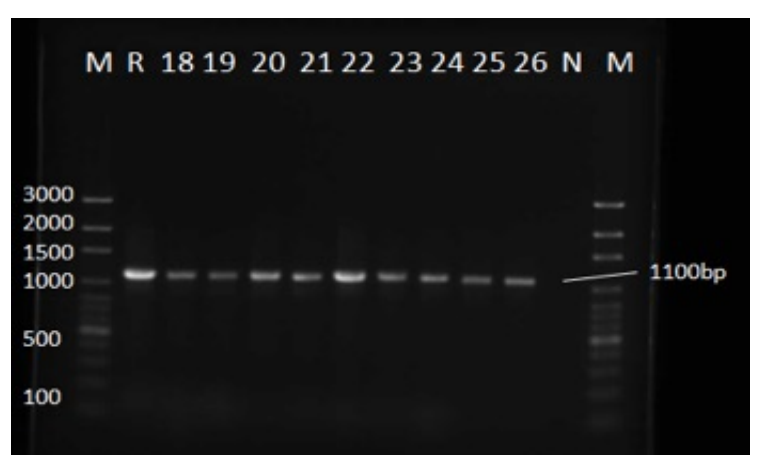

Şekil 1. Uygulanan PZR tekniği sonrası oluşan ürünlerin agaroz jel elektroforez sonucu. $\mathrm{M}$ : marker, 100 bç'lik DNA ladder, R: pozitif kontrol L. garvieae (ATCC 43921) suşu, N: negatif kontrol $A$. hydrophila (ATCC 19570) suşu, 18-26: pozitif suşlar.

Figure 1. Results of agarose gel electrophoresis of the amplification products after PCR technique. M: marker, 100 bp DNA ladder, R: positive control $L$. garvieae (ATCC 43921) strain, N: negative control $A$. hydrophila (ATCC 19570) strain, 18-26: positive strains.

Bu çalışmada 55 suşun antimikrobiyal duyarlılık test sonuçlarına göre, suşların tamamının basitrasin, kanamisin ve trimetoprim'e dirençli olduğu, 40 suşun flumekuin'e direnç gösterirken 54 suşun ise eritromisin'e duyarlı olduğu tespit edilmiştir. 55 suştan 20'si oksitetrasiklin'e orta düzeyde, 50 suşun ise furazolidon'a orta düzeyde dirençli oldukları belirlenmiştir. Antimikrobiyal duyarlılık test sonuçları genel olarak değerlendirildiğinde suşların basitrasin, kanamisin, trimetoprim, flumekuin, streptomisin, ampisilin, oksitetrasiklin ve furazolidon'a dirençli oldukları tespit edilmiştir. Hasta balıkların histopatolojik muayenesinde solungaçlarda hiperplazi ve füzyondan kaynaklanan doku bozulması (Şekil 2), solungaç filamentlerinde telangiectasia (Şekil 3), böbrek glomeruli ve tübüllerinde nekroz, hepatositlerde dejeneratif ve nekrotik dejenerasyonlar, midenin Lamina probria ve mukoza epitelyumunda boşalmalar tespit edilmiştir. Dalak ve böbrekte yoğun hemosiderin birikimi ile melanomakrofaj merkezlerinin aktivasyonunda artış da gözlenmiştir (Şekil 4, 5). Bazı balıklarda ise böbrek dokusu etrafında bakteriyel kolonilerin bulunduğu tespit edilmiştir (Şekil 6).

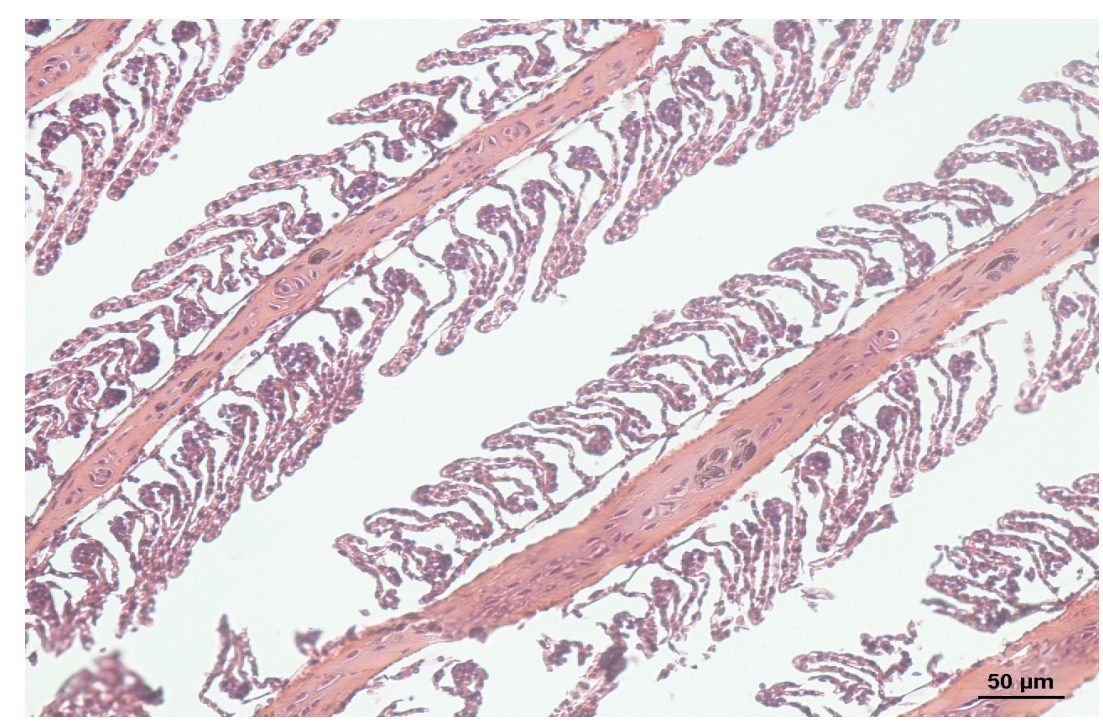

Şekil 2. Hiperplazi ve füzyon gösteren gökkuşağı alabalığı solungacı (H+E, Bar=50 $\mu \mathrm{m})$.

Figure 2. Gill of rainbow trout showing hyperplasia and fusion $(H+E, B a r=50 \mu m)$. 


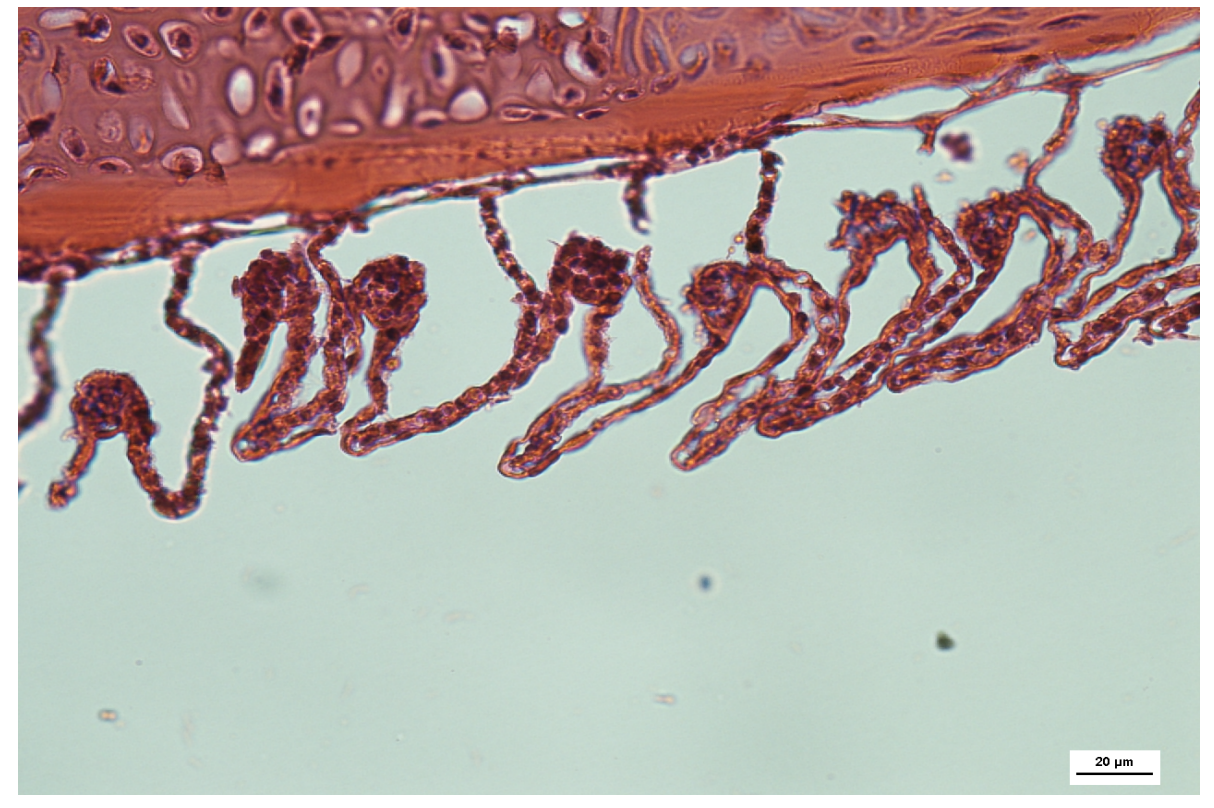

Şekil 3. Telangiectasia gösteren solungaç filamentleri (yıldız) ( $H+E, B a r=20 \mu m)$.

Figure 3. Gill filaments showing telangiectasia $(H+E, B a r=20 \mu m)$.

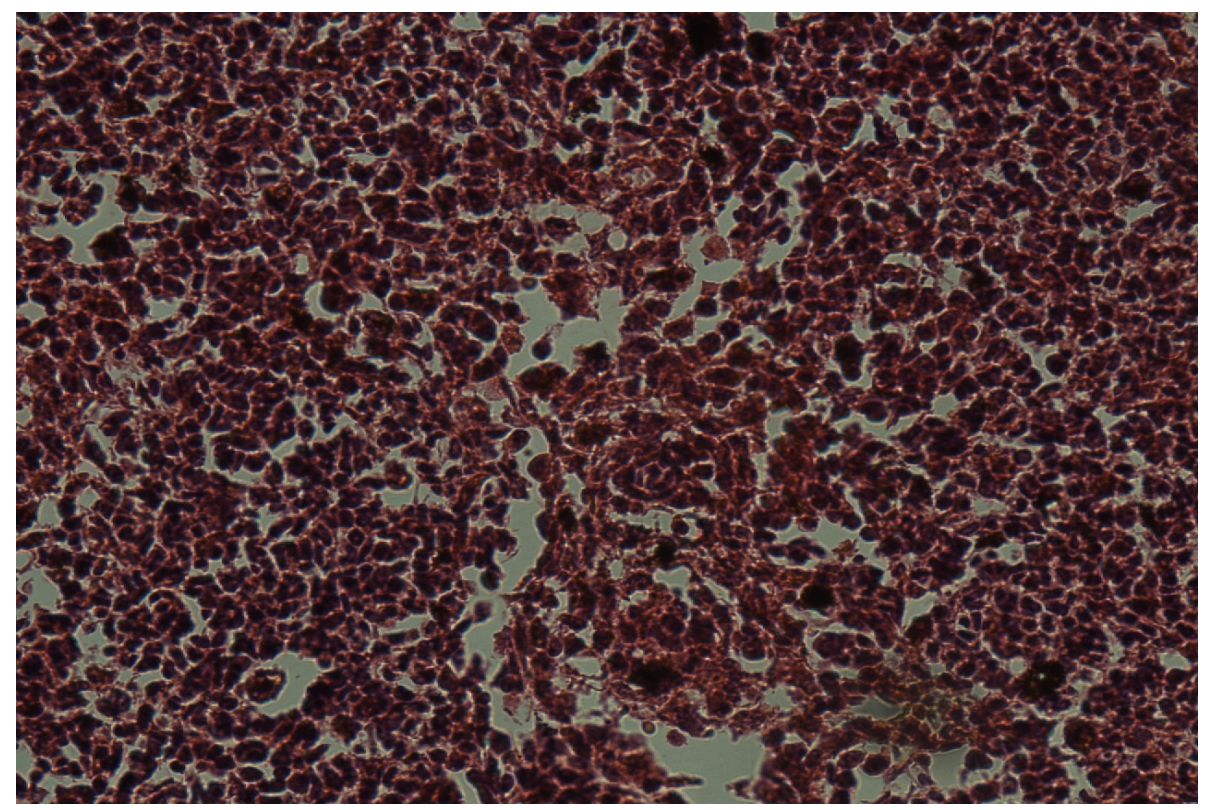

Şekil 4. Dalakta melanomakrofaj merkezlerinin aktivasyonu ( $\mathrm{H}+\mathrm{E}, \mathrm{Bar}=50 \mu \mathrm{m})$.

Figure 4. Activation of melanomacrophage centers in the spleen $(H+E, B a r=20 \mu m)$. 


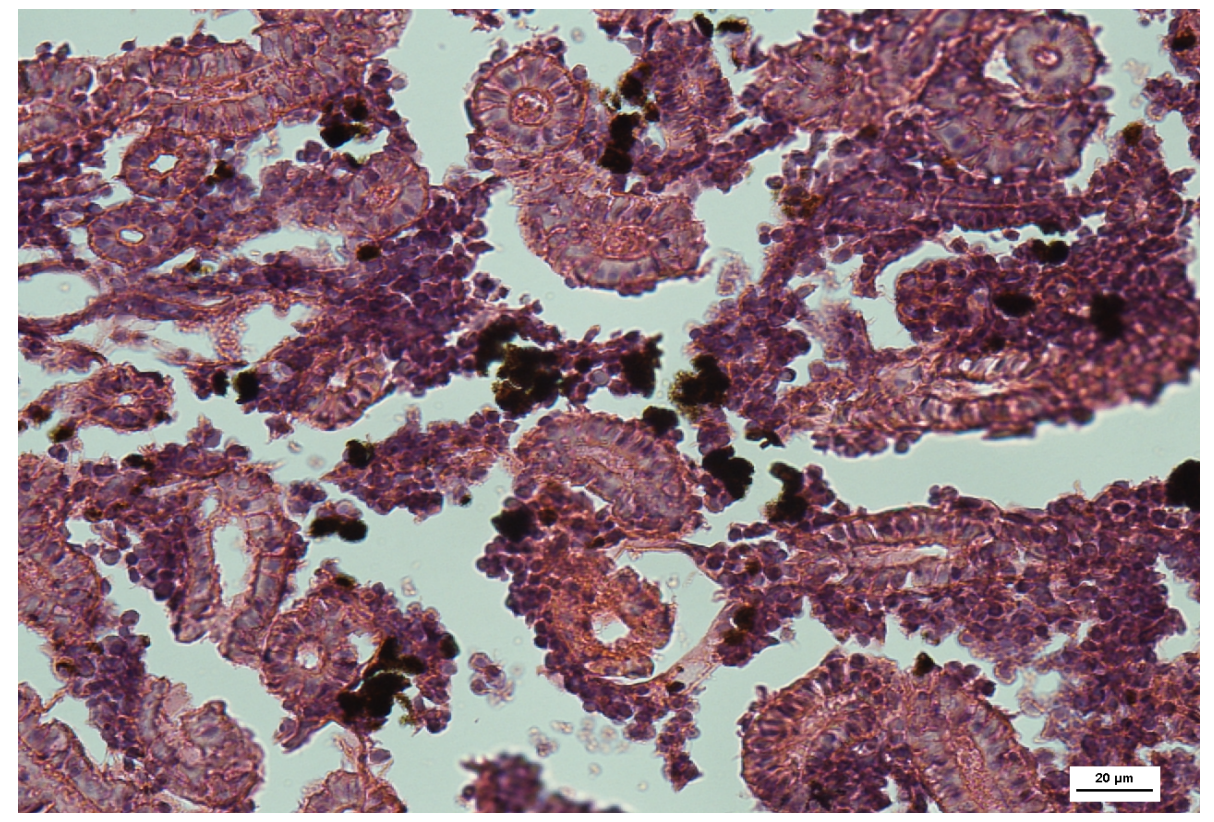

Şekil 5. Böbrekte melanomakrofaj merkezlerinin aktivasyonu ( $(\mathrm{H}+\mathrm{E}, \mathrm{Bar}=20 \mu \mathrm{m})$.

Figure 5. Activation of melanomacrophage centers in the kidney $(H+E, B a r=20 \mu m)$.

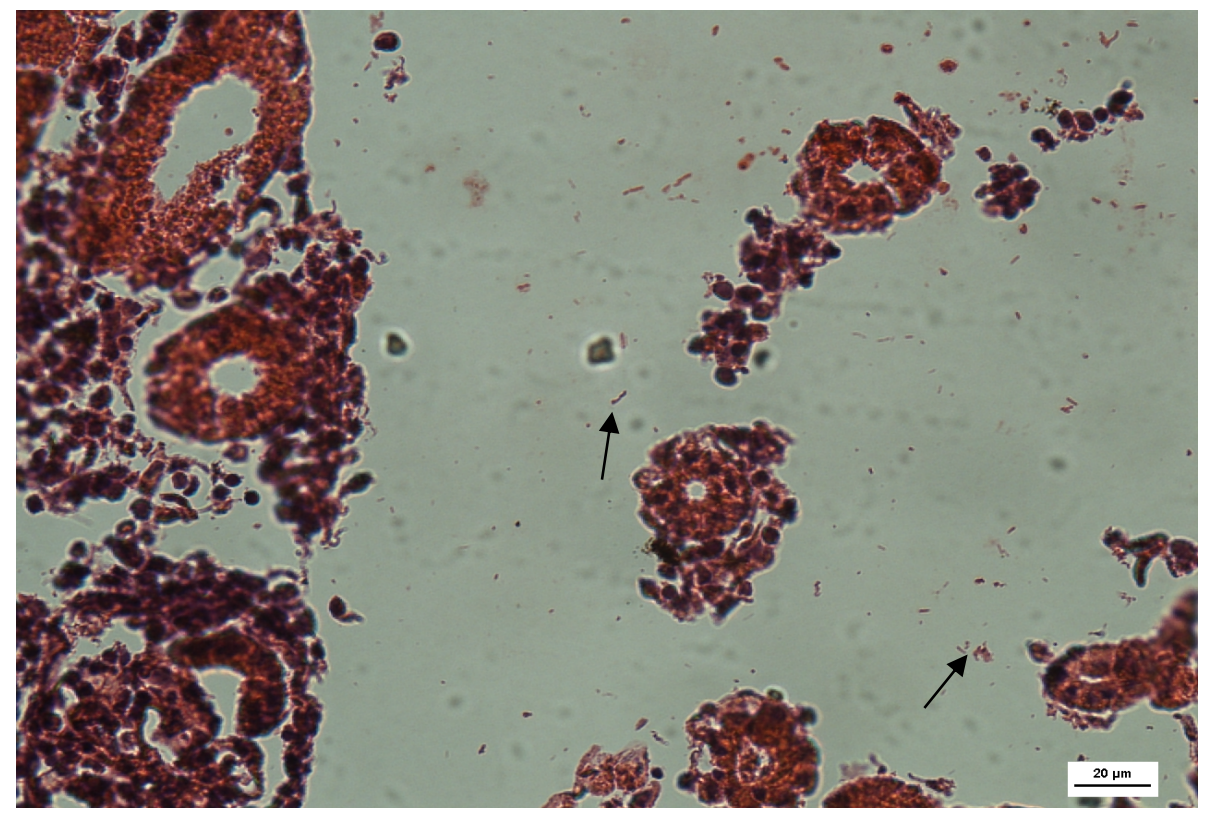

Şekil 6. Renal doku etrafında bakteri kolonilerinin bulunması (okla gösterilmiştir) (H+E, Bar=20 $\mu \mathrm{m})$.

Figure 6. Occurence of bacterial colonies surrounding the renal tissue (shown by arrow) $(H+E, B a r=20 \mu m)$.

\section{TARTIŞMA ve SONUÇ}

L. garvieae, S. iniae, S. agalactiae ve $S$. parauberis türleri su sıcaklığının $15{ }^{\circ} \mathrm{C}$ ve üzerine çıktığı dönemlerde gerek tatlı su gerek deniz balıklarında septisemiye neden olarak önemli ekonomik kayıplarla sonuçlanan enfeksiyonlara neden olduğu bildirilmiştir (4). Hastalıklı balıklarda tek ya da iki tarafı ekzoftalmi, gözde periorbital ve intraoküler bölgede, yüzgeçlerin taban kısımlarında, perianal bölgede hemorajiler, abdominal kısımda şişkinlik ve anüste prolapsus görüldüğü bildirilmiştir (17-19). Nekropside peritoneal asidik sıvı birikimi, 
karaciğer, dalak ve böbrek dahil iç organlarda hemoraji, dalak ve karaciğerde fokal nekroz ile bağırsakta kanlı sıvı birikiminin varlığı bildirilmiştir (17-19). Muğla ve Antalya civarındaki farklı gökkuşağı alabalığı işletmelerinde gözlenen hastalık çıkışlarından L. garvieae, S. iniae ve S. agalactiae' nin sorumlu olup olmadıklarının araştırıldığı bu çalışmaya su sıcaklığının $18{ }^{\circ} \mathrm{C}$ olduğu Nisan ayında başlanılıp su sıcaklığının $25^{\circ} C^{\prime}$ ye yükseldiği Eylül ayında tamamlanmıştır. Farklı işletmelerden yapılan örnekleme çalışmalarında hastalıktan etkilenen balıklarda genel olarak iştahsızlık, durgunluk, renkte koyulaşma, bilateral ekzoftalmi, hemoraji ve opaklaşma, abdominal şişkinlik ve anal prolapsus ile solungaçlarda solgunluk tespit edilmiştir. Nekropside, vücut kası ile hava kesesinde hemoraji, dalağın renginde koyulaşma, splenomegaly ve barsakta sarımsı renkli kanlı sıvı birikimi gözlenmiştir. Hasta balıklarda gözlenen bu bulgular, diğer araştırmacılar (17-19) tarafından L. garvieae ile enfekte gökkuşağı alabalıklarından bildirilen bulgulara benzerlik gösterdiği tespit edilmiştir. $L$. garvieae fakültatif anaerobik, hareketsiz, spor oluşturmayan, Gram-pozitif kok şekilli bir bakteridir. Tür, çiftler ve kısa zincirler şeklinde bulunur. $L$. garvieae kanlı vasatta $\alpha$-hemoliz oluştururken, sitokrom oksidaz ve katalaz negatif özellik göstermektedir $(4,18)$. Altun ve ark. (17) gökkuşağı alabalıklarından izole edilen sekiz $L$. garvieae suşunun sitokrom oksidaz ve katalaz negatif, VP pozitif olduğunu, $4{ }^{\circ} \mathrm{C}$ ile $45{ }^{\circ} \mathrm{C}$ de gelişme gösterdiğini, glikoz, früktoz, galaktoz, mannitol ve sakkarozu fermente ettiğini bildirmiştir. Suşlar $\alpha$ hemolitik olup MacConkey agarda koloni oluşturmuştur. 8 L. garvieae suşu nişasta ve jelatini hidrolize edemezken, \%6.5 $\mathrm{NaCl}$ de gelişme göstermiştir. Kav ve Erganiş (18) çalışmalarında $30 \mathrm{~L}$. garvieae suşunun glikoz, galaktoz, mannitol, sakkaroz, früktoz ve arabinoz'dan asit üretimlerinin pozitif olduğunu ancak sorbitol ile ksiloz'dan asit üretimlerinin ise negatif olduğunu bildirmiştir. $\mathrm{Bu}$ çalışmada L. garvieae suşunun Gram-pozitif, fermentatif, sitokrom oksidaz ve katalaz negatif ile
VP pozitif olduğu tespit edilmiştir. Suşlar, Anshary ve ark. (8), Altun ve ark. (17) ile Kav ve Erganiş (18) tarafından bildirildiği gibi $\alpha$-hemolitik olup, $45^{\circ} \mathrm{C}$ ve \%6.5 NaCl de geliştiği, glikoz, galaktoz, mannitol ve sakkaroz'u fermente ettiği belirlenmiştir. Bu çalışmada 55 suşun Altun ve ark. (17) tarafından bildirildiği gibi nişasta ve jelatini hidrolize edemedikleri ancak Altun ve ark. (17) tarafından bildirilenden farklı olarak suşların MacConkey agar da koloni oluşturmadıkları tespit edilmiştir. Bu çalışmada suşların sorbitol ve ksilozdan asit üretimlerinin pozitif olup Kav ve Erganiş (18) ise çalıştıkları L. garvieae suşlarının sorbitol ve ksilozdan asit üretimlerinin negatif olduğunu bildirmiştir. Streptokokkozis, Rapid ID 32 ve API 20 strep testleri ile kolay ve hızlı bir şekilde teşhis edilebilmekte ancak $L$. garvieae ile $L$. lactis subsp. lactis veya $S$. iniae ile $S$. uberis türlerinin biyokimyasal testlerinin benzerliğinden dolayı Streptokokkozis'in etiyolojik etkenleri birbirinden kesin olarak ayırt edilmediği bildirilmiştir (18). Kav ve Erganiş (18) 30 L. garvieae izolatının API 20 testinin 24 saatlik test sonuçlarına göre \%90 oranında L. lactis subsp. lactis ve \%6.6 oranında da $E$. faecalis'e benzerlik gösterdiğini bildirilmiştir. Bu çalışmada 55 suşun API 20 test sonuçlarının, Kav ve Erganiş (18) tarafından elde edilen sonuçlara benzerlik gösterdiği anlaşılmıştır. Biyokimyasal özelliklerdeki farklar, bir organizmanın fizyolojik profili üzerine önemli bir bilgi vermektedir. Bununla birlikte, fenotipik özellikler ile tek başına tür seviyesinde yeterli tanımlama yapılamamaktadır. Moleküler teknikler ile patojenik türleri tanımlama ve suşlar arasındaki farkı tür düzeyinde tespit edebilmenin mümkün olduğu bildirilmiştir (8). Ravelo ve ark. (14) L. garvieae suşları arasındaki genetik çeşitliliği değerlendirmek için RAPD (Rastgele Arttırılmış Polimorfik DNA) tekniğini kullandıkları çalışmada, suşların 1100 bç'lik spesifik amplifikasyon ürünü verdiğini bildirmiştir. Bu çalışmada, 55 L. garvieae suşunun identifikasyonu için uygulanan PZR tekniği sonuçlarına göre suşlar 1100 bç'lik amplikasyon ürünü vermiştir. Elde edilen sonuçların Ravelo ve ark. (14) tarafından bildirilen 
sonuçlar ile uyumlu olduğu anlaşılmıştır. Kav ve Erganiş (18) çalışmasında L. garvieae izolatlarının ampisilin, oksitetrasiklin ve eritromisin'e hassas olduklarını, Durmaz ve Kılıçoğlu (19) ise izole ettikleri L. garvieae izolatlarının ampisilin, eritromisin'e hassas, trimetoprim'e ise dirençli oldukları bildirilmiştir. Türe ve Boran (20) ampisilin'in L. garvieae suşlarına karşı en etkili ajanlar arasında olduğunu bildirmiştir. Bu çalışmada suşların eritromisin'e hassas olmaları, Kav ve Erganiş (18), Durmaz ve Kılıçoğlu (19) ile Türe ve Boran (20)'nın sonuçlarına benzerlik göstermekle birlikte, bu araştırıcılardan farklı olarak suşların oksitetrasiklin'e orta düzeyde direnç gösterdiği, ampisilin'e ise suşlar arasında farklı düzeyde direnç gösterdikleri belirlenmiştir. Avcl ve ark. (21) $L$. garvieae enfeksiyonundan etkilenen balıkların histopatolojik yönden incelenmesinde, balıkların solungaçlarında hemoraji, lamellar ödem ve telangiectasia bildirirken, Didinen ve ark. (22) ise laktokokkozis'den etkilenen balıklarda hepatositlerin nekrozunu bildirmiştir. Bu çalışmada hasta balıkların histopatolojik muayenesinde solungaç filamentlerinde telangiectasia, hepatositlerde ise nekrotik dejenerasyonlar gözlenmiştir. Bu bulgular Avcı ve ark. (21) ile Didinen ve ark. (22) tarafından bildirilen bulgulara benzerlik göstermiştir. Timur ve ark. (23) çalışmasında böbrek de melanomakrofaj merkezlerinde aktivasyon ve midenin mukoza epitelyumunda boşalma bildirmiştir. Bu çalışmada enfeksiyondan etkilenen balıklarda böbrekte melanomakrofaj merkezlerinde aktivasyon ile midenin Lamina probria ve mukoza epitelyumunda boşalmalar tespit edilmiştir. Bu bulgular, Timur ve ark. (23) tarafından bildirilen bulgulara benzerlik göstermiştir.

Sonuç olarak bu çalışmanın bulgularına göre, hasta gökkuşağı alabalıklarından Lactococcus garvieae izole edilirken gerek fenotipik tanı test sonuçlarına gerekse PZR çalışması sonuçlarına göre Streptococcus agalactiae (sin. S. difficilis) ve S. iniae izole ve identifiye edilememiştir. Çalışmanın bu sonucu ile, L. garvieae'nin bölgede örnekleme çalışması yapılan alabalık işletmelerinde görülen hastalık çıkışlarından sorumlu başlıca etken olduğu anlaşılmıştır. Çalışmada antibiyogram duyarlılık testi sonuçlarına göre, izolatların en az iki antimikrobiyal ajana dirençli oldukları bulunmuştur. Bu sonuca göre, laktokokkozis'e karşı mevcut aşı geliştirme çalışmalarının arttırılması gerektiği çünkü bakteride direnç gelişimi artmakla birlikte, bu direnç gelişiminin ortamda bulunan diğer bakteri türlerine de aktarılabileceğini düşündürmektedir.

\section{TEŞEKKÜR}

Bu çalışma Akdeniz Üniversitesi Bilimsel Araştırma Projeleri Koordinasyon Birimi tarafından desteklenmiştir. Proje No: 2011.01.0111.001.

\section{KAYNAKLAR}

1. Guijarro JA., Cascales D., Garcia-Dominguez M., Mendez J., 2015. Temperature-dependent expression of virulence genes in fish-pathogenic bacteria. Front Microbiol, 6, 700.

2. Sağlam YS., Işık N., Arslan A., Erer H., 2006. Erzurum Bölgesindeki gökkuşağı alabalıklarında (Oncorhynchus mykiss W. 1792) Aeromonas hydrophila ve Yersinia ruckeri izolasyonu ve patolojik incelemeler. Atatürk Üniversitesi Vet Bil Derg, 1, 6-10.

3. Onuk E., Durmaz Y., Çiftçi A., Pekmezci G., Kılıçoğlu Y., 2015. Çeşitli balık türlerinden izole edilen patojen bakteriler ve antibiyotik direnç profilleri. Atatürk Üniversitesi Vet Bil Derg, 10 (3), 156-164.

4. Austin B., Austin DA., 2012. Bacterial Fish Pathogens. Diseases of Farmed and Wild Fish. 5th ed., 17-118, Springer Science, Dordrech.

5. Eldar A., Goria M., Ghittino C., Zlotkin A., 1999. Biodiversity of Lactococcus garvieae strains isolated from fish in Europa, Asia, and Australia. Appl Environ Microbiol, 65, 1005-1008.

6. Anshary H., Kurniawan RA., Sriwulan S., Ramli R., Baxa DV., 2014. Isolation and molecular identification of the etiological agents of streptococcosis in Nile tilapia (Oreochromis 
niloticus) cultured in net cages in Lake Sentani, Papua, Indonesia. Singer Plus, 3, 627-638.

7. Mata Al., Gibello A., Casamayor M., Blanco MM., Dominguez L., Fernandez-Garayzabal JF., 2004. Multiplez pcr assay for detection of bacterial pathogens associated with water streptococcosis in fish. Appl Environ Microbiol, 70, 3138-3187.

8. Vendrell D., Balcazar JL., Ruiz-Zarzuela I., de Blas I., Girones O., Muzquiz JL., 2006. Lactococcus garvieae in fish: a review. Comp Immunol Microbiol Infect Dis, 29, 177-198.

9. Diler Ö., Altun S., Adiloğlu A., Kubilay A., Işıklı BI., 2002. First occurence of streptococcosis affecting farmed rainbow trout (Oncorhynchus mykiss) in Turkey. Bull Eur Ass Fish Pathol, 22, 21-26.

10. Öztürk RÇ., Altınok İ., 2014. Bacterial and viral fish diseases in Turkey. Turk J Fish Aquat Sci, 14, 275-297.

11. Buller NB., 2009. Interpretation of biochemical identification tests and sets. In "Bacteria from Fish and Other Aquatic Animals", 1st ed., 127, CABI Publishing, South Peth.

12. CLSI, 2006. Clinical and Laboratory Standards Institute Methods for Antimicrobial Disk Susceptibility Testing of Bacteria Isolated from Aquatic Animals: Approved Guideline. CLSI Document M42-A, USA.

13. Zlotkin A., Eldar A., Ghittino C., Bercovier A., 1998. Identification of Lactococcus garvieae by PCR. J Clin Microbiol, 36, 983-985.

14. Ravelo C., Magarinos B., Lopez-Romalde S., Toranzo AE., 2003. Molecular fingerprintings of fish-pathogenic Lactococcus garvieae strains by random amplified polymorphic DNA analysis. J Clin Microbiol, 41, 751-756.

15. Pourgholam R., Lalvei F., Saeedi AA., Zahedi A., Safari R., Taghavi MJ., Nasrollzadeh Saravi H., Pourgholam H., 2011. Distribution and molecular identification of some causative agents of streptococcosis isolated from farmed rainbow trout (Oncorhynchus mykiss, Walbaum) in Iran. Iran J Fish Sci, 10, 109-122.
16. Timur G., Timur M., 2003. Balık Hastalıkları, 384445, Rektörlük Yayın No: 4426, Su Ürünleri Yayın No:5, İstanbul.

17. Altun S., Diler Ö., Adiloğlu AK., 2004. Genotyping of Lactococcus garvieae from rainbow trout (Oncorhynchus mykiss) by 165 rDNA sequencing. Bull Eur Ass Fish Pathol, 24, 119-125.

18. Kav K., Erganiş O., 2007. Konya bölgesinde bulunan gökkuşağı alabalığı (Oncorhynchus mykiss) çiftliklerinden Lactococcus garvieae izolasyonu, identifikasyonu ve fenotipik özelliklerinin belirlenmesi. Vet Bil Derg, 23, 7-17.

19. Durmaz Y., Kılıçoğlu Y., 2015. Bir alabalık çiftliğinde doğal enfekte gökkuşağı alabalıklarından (Oncorhynchus mykiss, Walbaum, 1792) Lactococcus garvieae'nin kültür ve pcr ile saptanması ve etkenin antibiyotik duyarlılık profillerinin belirlenmesi. Atatürk Üniversitesi Vet Bil Derg, 10, 109-115.

20. Türe M., Boran H., 2015. Phenotypic and genotypic antimicrobial resistance of Lactococcus sp. strains isolated from rainbow trout (Oncorhynchus mykiss). Bull Vet Inst Pulawy, 59, 37-42.

21. Avcı H., Aydoğan A., Tanrıkul TT., Birincioğlu SS., 2010. Pathological and microbiological investigations in rainbow trout (Oncorhynchus mykiss Walbaum, 1792) naturally infected with Lactococcus garvieae. Kafkas Univ Vet Fak Derg, 16, 313-318.

22. Didinen BI., Yardımcı B., Onuk EE., Metin S., Yıldırım P., 2014. Naturally Lactococcus garvieae infection in rainbow trout (Oncorhynchus mykiss Walbaum, 1792) new histopathological observations, phenotypic and molecular identification. Rev Med Vet-Toulouse, 165, 1219.

23. Timur G., Yardımcı RE., Ülkü Ç., Çanak Ö., 2011. Diagnosis of lactococcosis by bacteriological and histopathological methods in farmed rainbow trout (Oncorhynchus mykiss) at the Marmara Region. Turkish J Aquat Sci, 26, 63-81. 